\title{
Flood refuge measures in the vicinity of urban rivers
}

\author{
H. Gotoh, M. Takezawa, Y. Maeno \& H. Oshiki \\ College of Science and Technology, Nihon University, Japan
}

\begin{abstract}
Flood hazards in urban areas have decreased markedly in recent years due to the implementation of measures such as dikes, weirs, water gates and other mitigation methods. Consequently, the population of developed or redeveloped urban areas near river basins and coastal areas has increased considerably, and a concomitant increase has been observed in the number of high-rise office buildings and apartments on the alluvium of old urban rivers. While the residents of these structures are sensitive to earthquake damage, they are relatively unaware of the risks associated with flooding. While several flood refuges exist in the vicinity of urban rivers, the intended purpose of these refuges has come to be regarded as that of earthquake emergency measures rather than a measure intended for flooding. Consequently, the placement of many of these emergency refuges does not consider the risk of inundation.

In this report, the present condition of such refuge sites in the low lying areas of Tokyo is examined. We also investigated the attitude of residents living in high-rise apartment buildings and detached houses toward flood hazards. Finally, we proposed flood refuge measures that could be implemented to minimize the risk of disaster.
\end{abstract}

Keywords: flooding, refuge site, attitude survey, high-rise apartment building.

\section{Introduction}

Recently, because of the associated convenience and good living environment, many people have moved to the urban coastal area of Tokyo. In response to this increased demand, numerous detached houses and high-rise apartment buildings have been built by developers in this area, despite the fact that the coastal areas of Tokyo are potentially at risk from flooding. This increased risk is primarily 
due to the fact that the ground level in this area, also called the 'zero meter area' which extends over $84.9 \mathrm{~km}^{2}$, is below sea level and the level of the water in the rivers that drain the area. In addition, since the early 20th century, extensive land subsidence has occurred due to excessive groundwater extraction for industrial use; the largest example of subsidence is approximately 4.5 meters [1]. Fortunately, such subsidence has ceased because of government regulations "Law of industrial water" that prohibit the drawing of groundwater [2].

We previously surveyed the attitudes' of residents of detached houses regarding flood hazards [3]. In this report, the report on the condition of refuge sites intended for flooding in the low lying areas of Tokyo. In addition, we investigated the attitude of residents living in high-rise apartment buildings toward flood hazards, and compared their responses with those of people residing in detached houses. Finally, we propose flood disaster measures for keeping flood-related damage to a minimum.

\section{Present conditions of refuge sites in the low lying areas of Tokyo}

The Tokyo metropolitan government has prepared several sites for refuge from disasters such as earthquakes, large fires, and flooding. Compared to the well developed system of refuge sites for earthquakes and/or large fires, the systems developed for flooding are less well prepared.

This is particularly apparent in the low lying Koutou area (zero meter area) in the metropolitan area of Tokyo where the ground level is lower than the water level in the rivers and adjacent ocean as shown in Figure 1 [4]. Nonetheless, extensive residential developments have been undertaken in the previous ten years in the area, including the high-rise apartment buildings shown in Figure 2. This situation has necessitated a reduction in the mean water level of the rivers flowing through the Koutou by pumping, and Figure 3 shows the facilities that are currently used to mitigate the risk of flooding [1].

As shown in Figure 4, while numerous refuge sites have been designated in the Koutou area, most are existing buildings belonging to public institutions such as schools and community centers [5]. Interestingly, of the refuge sites currently

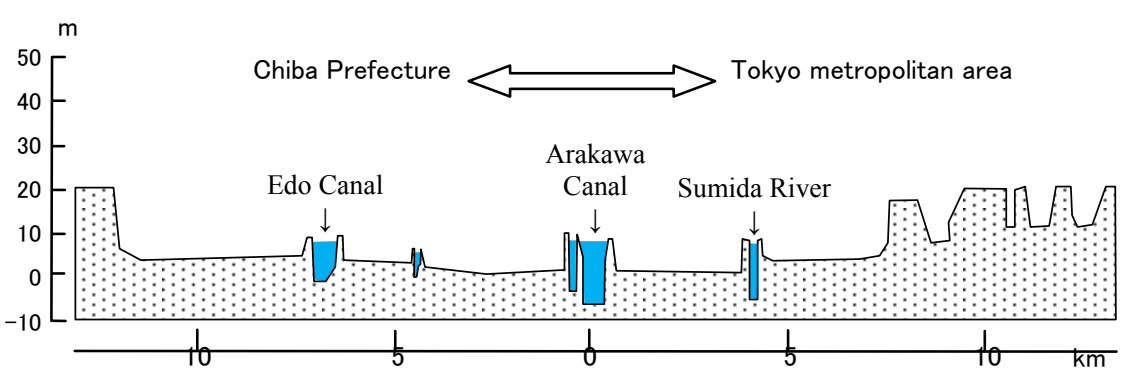

Figure 1: Schematic cross-section of the "zero meter" (Koutou) area in Tokyo [4]. 


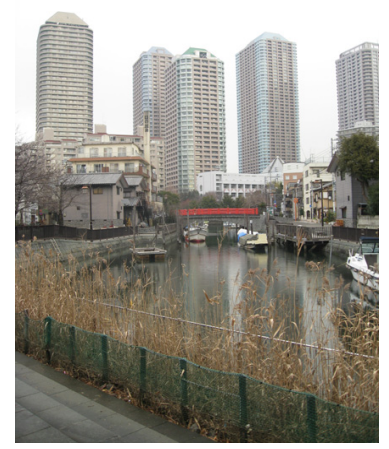

Figure 2: Example of recent residential development in the coastal area around Tokyo Bay.

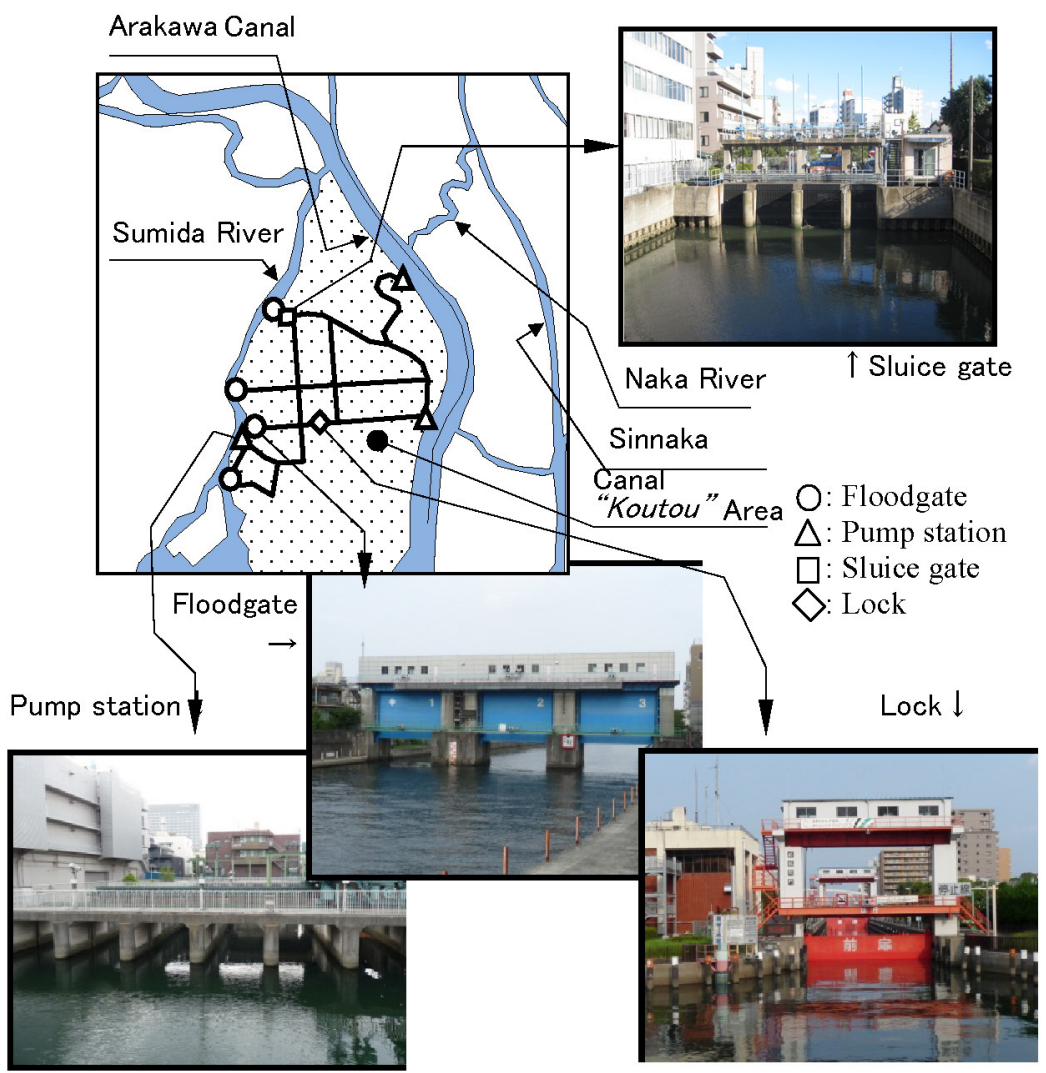

Figure 3: $\quad$ Flood mitigation facilities [1]. 


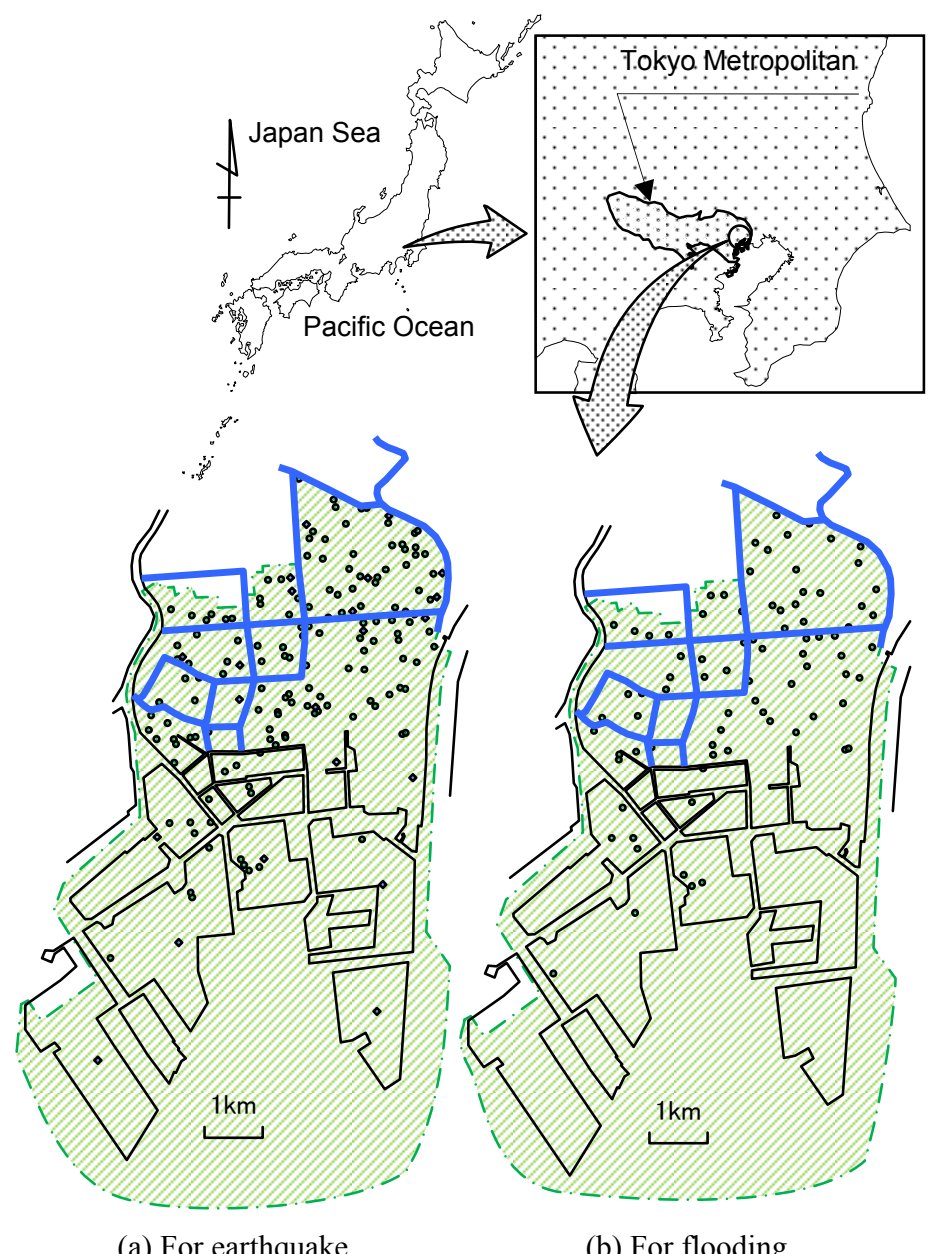

(a) For earthquake

(b) For flooding

Figure 4: Location of refuge sites in a section of the "zero meter" (Koutou) area [5].

designated by the government, high-rise buildings have not been considered. We propose that, if the government were able to reach consensus with the residents of existing high-rise buildings, that such buildings could be used as refuge sites during episodes of flooding. It is therefore important to ascertain the attitude of residents living in high-rise buildings toward flood hazards.

\section{Summary of attitude survey}

The survey to ascertain the attitudes of residents in high rise buildings was conducted in the Koutou region at the sites shown in Figure 5. For the residents of detached houses, 500 questionnaires were randomly distributed to residents in 
the area. For the residents of high-rise apartment buildings, we selected one or two apartment buildings in every area shown in Figure 5 and distributed questionnaires to all apartments. The list of questions posed to residents is shown in Table 1.

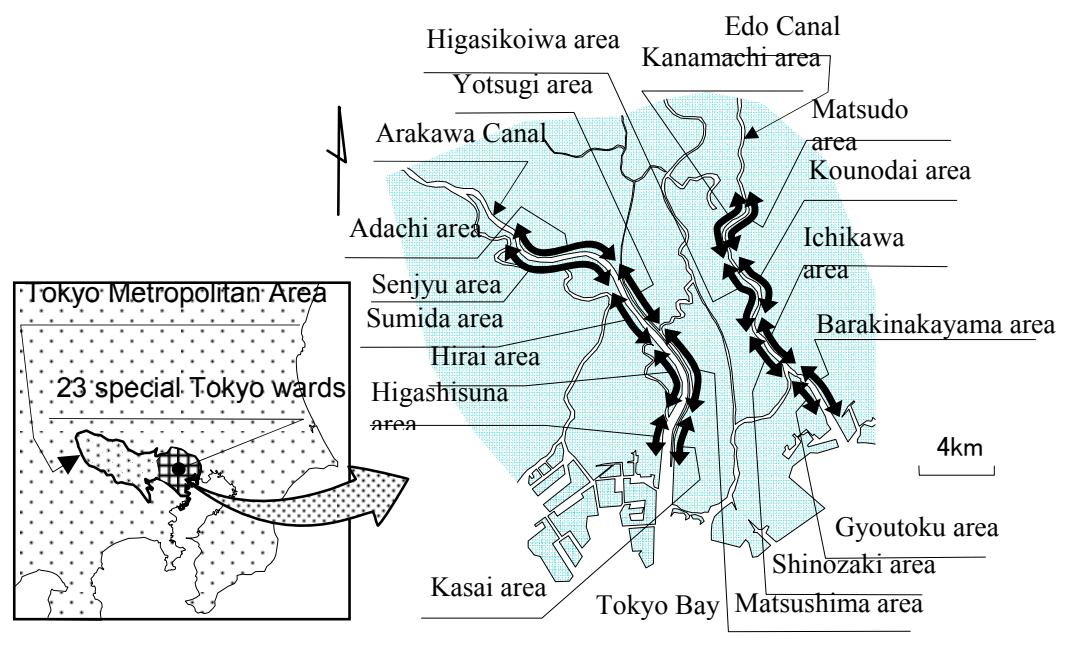

Figure 5: Description of surveyed area.

Table 1: Questionnaire items submitted to residents.

Please answer the questions below:

1. Sex? (Male or Female?) 2. Age? 3. Occupation?

4. How long have you lived in your house?

5. Do you believe you are at risk of flooding? (Yes or No)

6. Are you intimidated by the height of the levee? (Yes or No)

7. Have you walked on the levee? (Yes or No)

8. Do you think that the height and the breadth of levees are sufficient? (Yes or No)

9. Has your property ever been damaged by flooding? (Yes or No)

10. Do you believe you are at risk of tidal waves or tsunami? (Yes or No)

11. Do you believe that the levee is sufficiently strong to withstand an earthquake? (Yes or No)

12. In case of flooding, do you know the location of your designated evacuation area? (Yes or No)

13. Do you believe the designated evacuation area is safe? (Yes or No)

14. Is the evacuation area far from your place of residence? (Yes or No)

15. Do you believe your residential area has a good environment? (Yes or No)

16. Do you believe there are enough convenient facilities (train station, shops etc.) for living in your residential area? (Yes or No)

17. Do you have opinions on the disaster prevention measures related to the Arakawa Canal and Edo Canal?

Table 2 summarizes the building characteristics of the high-rise apartment buildings surveyed, including the number of distributed questionnaires and the response rate. As can be seen in the table, the average response rate was $20.8 \%$, which was similar to that of the residents of the detached houses [3]. 
Table 2: Summary of number of stories, number of distributed questionnaires and response rate.

\begin{tabular}{|c|c|c|c|c|c|c|c|}
\hline \multicolumn{4}{|c|}{ Arakawa Canal Basin } & \multicolumn{4}{|c|}{ Edo Canal Basin } \\
\hline Area & $\begin{array}{c}\text { Number } \\
\text { of stories }\end{array}$ & Apartments & $\begin{array}{c}\text { Response } \\
\text { rate }(\%)\end{array}$ & Area & $\begin{array}{c}\text { Number } \\
\text { of stories }\end{array}$ & Apartments & $\begin{array}{c}\text { Response } \\
\text { rate }(\%)\end{array}$ \\
\hline $\begin{array}{c}(1) \\
\text { Senjyu }\end{array}$ & $\begin{array}{l}7 \\
9\end{array}$ & $\begin{array}{l}39 \\
36\end{array}$ & $\begin{array}{l}12.0 \\
(9 / 75)\end{array}$ & $\begin{array}{c}(9) \\
\text { Kana- } \\
\text { machi }\end{array}$ & 5 & 95 & $\begin{array}{c}25.3 \\
(24 / 95)\end{array}$ \\
\hline $\begin{array}{c}\text { (2) } \\
\text { Sumida }\end{array}$ & $\begin{array}{l}7 \\
8\end{array}$ & $\begin{array}{l}78 \\
37\end{array}$ & $\begin{array}{c}13.9 \\
(16 / 115)\end{array}$ & $\begin{array}{c}(10) \\
\text { Higashi- } \\
\text { koiwa }\end{array}$ & $\begin{array}{l}7 \\
5\end{array}$ & $\begin{array}{l}31 \\
18\end{array}$ & $\begin{array}{c}14.3 \\
(7 / 49)\end{array}$ \\
\hline $\begin{array}{c}(3) \\
\text { Hirai }\end{array}$ & 13 & 87 & $\begin{array}{c}31.0 \\
(27 / 87)\end{array}$ & $\begin{array}{c}(11) \\
\text { Shinozaki }\end{array}$ & $\begin{array}{l}6 \\
5 \\
\end{array}$ & $\begin{array}{l}22 \\
57 \\
\end{array}$ & $\begin{array}{c}15.2 \\
(12 / 79) \\
\end{array}$ \\
\hline $\begin{array}{c}\text { (4) } \\
\text { Higashi- } \\
\text { suna }\end{array}$ & $\begin{array}{c}9 \\
15\end{array}$ & $\begin{array}{l}39 \\
99\end{array}$ & $\begin{array}{c}17.4 \\
(24 / 138)\end{array}$ & $\begin{array}{c}(12) \\
\text { Gyoutoku }\end{array}$ & 6 & 54 & $\begin{array}{c}24.1 \\
(13 / 54)\end{array}$ \\
\hline $\begin{array}{c}(5) \\
\text { Adachi } \\
\end{array}$ & 9 & 101 & $\begin{array}{c}35.3 \\
(30 / 85) \\
\end{array}$ & $\begin{array}{c}\text { (13) } \\
\text { Matsudo }\end{array}$ & $\begin{array}{l}6 \\
7 \\
\end{array}$ & $\begin{array}{l}48 \\
52 \\
\end{array}$ & $\begin{array}{c}21.0 \\
(21 / 100) \\
\end{array}$ \\
\hline $\begin{array}{c}\text { (6) } \\
\text { Yotsugi }\end{array}$ & 7 & 82 & $\begin{array}{c}20.7 \\
(17 / 82)\end{array}$ & $\begin{array}{c}(14) \\
\text { Kounodai }\end{array}$ & 13 & 117 & $\begin{array}{c}23.1 \\
(27 / 117) \\
\end{array}$ \\
\hline $\begin{array}{c}\text { (7) } \\
\text { Matsu- } \\
\text { shima } \\
\end{array}$ & 8 & 89 & $\begin{array}{c}27.0 \\
(24 / 89)\end{array}$ & $\begin{array}{c}(15) \\
\text { Ichikawa }\end{array}$ & 9 & 96 & $\begin{array}{c}28.1 \\
(27 / 96)\end{array}$ \\
\hline $\begin{array}{c}(8) \\
\text { Kasai }\end{array}$ & $\begin{array}{l}7 \\
7\end{array}$ & $\begin{array}{l}29 \\
36\end{array}$ & $\begin{array}{c}7.7 \\
(5 / 65)\end{array}$ & $\begin{array}{c}(16) \\
\text { Baraki- } \\
\text { nakayama }\end{array}$ & 6 & 49 & $\begin{array}{c}17.1 \\
(7 / 49)\end{array}$ \\
\hline Total & - & 752 & $\begin{array}{c}20.2 \\
(152 / 752)\end{array}$ & Total & - & 639 & $\begin{array}{c}21.6 \\
(138 / 639)\end{array}$ \\
\hline
\end{tabular}

The total of number of respondents in high-rise buildings was 289 (153 males and 136 females). Male respondents were primarily company employees and the majority of female respondents were housewives. The average age of respondents was approximately 50 years old; this profile was same as the case of respondents living in detached houses. In addition, the average age of the highrise buildings in the survey was 15 years, and the average duration of stay by the respondents of those buildings was 11 years.

Table 3 shows the proportions of "YES" answers to the survey questions (Qs.5 to 16) by respondents in both high-rise buildings and that of detached houses in the survey area. Some considerations regarding the result of the questionnaire are as follows:

Question on Flooding[Q.5] Regarding Q.5, 42.6\% of respondents living in the Arakawa canal basin are anxious about flooding, with 1.5 as many residents from the Arakawa canal basin fearing flooding compared to residents in the Edo canal basin. In addition, in the case of the Arakawa canal, respondents living on the left side toward the downstream are particularly anxious about flooding. In addition, for both rivers the proportion of anxious respondents increases as one moves downstream.

Questions on levee[Q.6, 7, 8] Most of respondents have walked on the levee along the river (Q.7). However, in comparison with residents of the Edogawa canal basin (Q.6), 3.4 times as many residents in the Arakawa canal basin fear the height of the levee, particularly in the lower reaches of the Arakawa canal. Of the responses for Q.8, in increasing order of perceived flooding risk by 
Table 3: Total results on the proportion of "YES" answers for high-rise buildings and detached houses [1].

\begin{tabular}{|c|c|c|c|c|c|c|c|c|c|c|c|c|c|c|}
\hline & $\begin{array}{c}\text { Area } \\
\Omega\end{array}$ & $\begin{array}{l}\text { Type of } \\
\text { house } \\
\square\end{array}$ & 3 & ß & 3 & 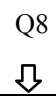 & 凸 & $\begin{array}{l}\text { Q10 } \\
3\end{array}$ & Q11 & Q12 & $\begin{array}{l}\text { Q13 } \\
\text { R }\end{array}$ & $\begin{array}{l}\text { Q14 } \\
\text { 乃 }\end{array}$ & $\begin{array}{l}\text { Q15 } \\
\text { ת }\end{array}$ & $\begin{array}{l}\text { Q16 } \\
\text { R }\end{array}$ \\
\hline \multirow{25}{*}{ 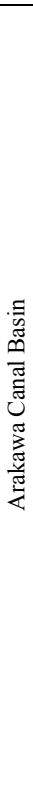 } & \multirow{2}{*}{$\begin{array}{c}(1) \\
\text { Senjyu }\end{array}$} & High-rise & 33.3 & 11.1 & 88.9 & 33.3 & 11.1 & 0 & 11.1 & 88.9 & 44.4 & 0 & 100 & 77.8 \\
\hline & & Detached & 41.3 & 4.0 & 82.7 & 2.0 & 28.7 & 21.3 & 31.3 & 77.3 & 32 & 32.7 & 81.3 & 73.3 \\
\hline & \multirow{2}{*}{$\begin{array}{c}(2) \\
\text { Sumida } \\
\end{array}$} & High-rise & 43.8 & 12.5 & 87.5 & 50.0 & 12.5 & 6.3 & 43.8 & 75.0 & 37.5 & 25.0 & 75.0 & 43.8 \\
\hline & & Detached & 37.9 & 14.5 & 90.3 & 61.3 & 23.4 & 21.0 & 30.6 & 84.7 & 26.6 & 8.2 & 68.5 & 68.5 \\
\hline & \multirow{2}{*}{$\begin{array}{c}(3) \\
\text { Hirai }\end{array}$} & High-rise & 18.5 & 3.7 & 92.6 & 66.7 & 25.9 & 14.8 & 48.1 & 85.2 & 66.7 & 0 & 88.9 & 51.9 \\
\hline & & Detached & 36.9 & 23.1 & 87.7 & 60.0 & 47.7 & 33.8 & 32.3 & 81.5 & 32.3 & 6.2 & 79.2 & 79.2 \\
\hline & \multirow{2}{*}{$\begin{array}{c}(4) \\
\text { Higashisuna } \\
\end{array}$} & High-rise & 37.5 & 16.7 & 95.8 & 70.8 & 4.2 & 37.5 & 50.0 & 66.7 & 37.5 & 16.7 & 100 & 83.3 \\
\hline & & Detached & 54.0 & 31.0 & 90.0 & 47.0 & 44.0 & 52.0 & 23.0 & 74.0 & 12.0 & 51.0 & 75.0 & 69.0 \\
\hline & \multirow{3}{*}{\begin{tabular}{|c|} 
Average of \\
right side of \\
canal toward \\
sea \\
\end{tabular}} & High-rise & 33.3 & 11.0 & 91.2 & 55.2 & 13.4 & 14.7 & 38.3 & 79.0 & 46.5 & 10.4 & 91.0 & 64.2 \\
\hline & & Detached & 42.5 & 23.2 & 87.7 & 55.1 & 36.0 & 32.0 & 29.3 & 79.4 & 25.7 & 42.0 & 76.0 & 72.5 \\
\hline & & Total & 37.9 & 17.1 & 89.4 & 55.1 & 24.7 & 23.3 & 33.8 & 79.2 & 36.1 & 26.2 & 83.5 & 68.4 \\
\hline & \multirow{2}{*}{$\begin{array}{c}(5) \\
\text { Adachi }\end{array}$} & Iigh-rise & 46.7 & 6.7 & 90.0 & 46.7 & 13.3 & 3.3 & 26.7 & 53.3 & 26.7 & 36.7 & 73.3 & 73.3 \\
\hline & & Detached & 47.0 & 15.7 & 94.8 & 48.7 & 53.9 & 24.3 & 33.0 & 80.9 & 29.6 & 22.6 & 67.8 & 43.5 \\
\hline & \multirow{2}{*}{$\begin{array}{c}(6) \\
\text { Yotsugi }\end{array}$} & High-rise & 17.6 & 17.6 & 94.1 & 58.8 & 11.8 & 1.8 & 41.2 & 70.6 & 23.5 & 7.6 & 32.4 & 70.6 \\
\hline & & Detached & 54.2 & 18.6 & 86.4 & 39.0 & 50.0 & 39.0 & 22.0 & 83.9 & 29.7 & 21.2 & \begin{tabular}{|l|}
67.8 \\
\end{tabular} & 75.4 \\
\hline & \multirow{2}{*}{$\begin{array}{c}(7) \\
\text { Matsushima } \\
\end{array}$} & High-rise & 37.5 & 20.8 & 70.8 & 54.2 & 16.7 & 33.3 & 37.5 & 83.3 & 54.2 & 25 & 95.8 & 91.7 \\
\hline & & Detached & 54.4 & 28.9 & 87.7 & 43.9 & 36.0 & 45.6 & 28.1 & 60.5 & 18.4 & 46.5 & 64.9 & 50.9 \\
\hline & \multirow{2}{*}{$\begin{array}{c}(8) \\
\text { Kasai }\end{array}$} & rise & 0.0 & 0 & 80.0 & 40.0 & 0 & 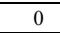 & 60.0 & 80.0 & 60.0 & 40.0 & 100 & 80.0 \\
\hline & & Detached & 60.2 & 8.8 & 85.7 & 32.7 & 35.7 & 52.0 & 12.2 & 71.4 & 19.4 & 35.7 & 73.5 & 82.7 \\
\hline & \multirow{3}{*}{$\begin{array}{c}\text { Average of } \\
\text { left side of } \\
\text { canal toward } \\
\text { sea } \\
\end{array}$} & High-rise & 40.5 & 18.8 & 83.7 & 49.9 & 10.5 & 12.1 & 41.4 & 71.8 & 41.1 & 29.8 & 87.9 & 78.9 \\
\hline & & ed & 54.0 & .5 & 887 & 41.1 & 43.9 & .2 & 220 & 4.2 & .3 & 1.5 & 8.5 & 3.1 \\
\hline & & Total & 47.2 & 22.1 & 86.2 & 45.5 & 27.2 & 26.2 & 32.6 & 73.0 & 32.7 & 30.7 & 78.2 & 71.0 \\
\hline & \multirow{3}{*}{ Average } & ise & 36.9 & 14.9 & 87.5 & 52.6 & 11.9 & 3.4 & 39.8 & 75.4 & 43.8 & 20.1 & 89.4 & 71.6 \\
\hline & & Detached & 48.2 & 24.3 & 88.2 & 48.1 & 39.9 & 36.1 & 26.6 & 76.8 & 25.0 & 36.8 & 72.3 & 67.8 \\
\hline & & Total & 42.6 & 9.6 & 87.8 & 50.3 & 25.9 & 24.8 & 33.2 & 76.1 & 34.4 & 28.4 & 80.8 & 69.7 \\
\hline \multirow{25}{*}{ 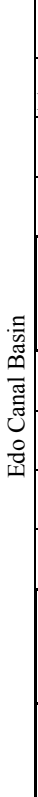 } & \multirow{2}{*}{$\begin{array}{c}(9) \\
\text { Kanamachi }\end{array}$} & Iigh-rise & 20.8 & 0 & 100 & 75.0 & 0 & 8.3 & 62.5 & 91.7 & 50.0 & 20.8 & 100 & 62.5 \\
\hline & & Detached & 26.1 & 4.3 & 94.9 & 73.9 & 31.9 & 13.0 & 52.2 & 85.5 & 43.5 & 18.1 & 93.5 & 74.6 \\
\hline & \multirow{2}{*}{$\begin{array}{c}(10) \\
\text { Higashikoiwa } \\
\end{array}$} & -rise & 28.6 & 0 & 71.4 & 42.9 & 0 & 0 & 14.3 & 71.4 & 28.6 & 2.9 & 85.7 & 85.7 \\
\hline & & & 35.3 & 10.8 & 95.1 & 64.7 & 5.5 & 15.7 & 50.0 & 80.4 & 43.1 & 10.8 & 97.1 & 73.5 \\
\hline & \multirow{2}{*}{$\begin{array}{c}(11) \\
\text { Shinozaki }\end{array}$} & ise & 16.7 & 8.3 & 91.7 & 83.3 & 0 & 8.3 & 58.3 & 75.0 & 25.0 & 16.7 & 75.0 & 66.7 \\
\hline & & Detached & 34.2 & 9.2 & 94.7 & 65.8 & 9.2 & 25.0 & 40.8 & 89.5 & 50.0 & 18.4 & 92.1 & 68.4 \\
\hline & & -rise & 7.7 & 7.7 & 76.9 & 61.5 & 0 & 0 & 53.8 & 84.6 & 53.8 & 15.4 & 92.3 & 92.3 \\
\hline & Gyoutoku & Detached & 43.4 & 6.6 & 84.9 & 59.4 & 17.0 & 34.9 & 46.2 & 91.5 & 49.1 & 18.9 & 83.0 & 86.8 \\
\hline & Average of & High-rise & 18.5 & 4.0 & 85.0 & 65.7 & 0.0 & 4.2 & 47.2 & 80.7 & 39.4 & 24.0 & 88.3 & 76.8 \\
\hline & & Detached & 34.8 & 7.7 & 92.4 & 66.0 & 20.9 & 22.2 & 47.3 & 86.7 & 46.4 & 16.6 & 91.4 & 75.8 \\
\hline & $\begin{array}{r}\text { canal to } \\
\text { sea }\end{array}$ & al & 26.6 & 5.9 & 88.7 & 65.8 & 10.5 & 13.2 & 47.3 & 83.7 & 42.9 & 20.3 & 89.8 & 76.3 \\
\hline & (13) & & & & & & & t. & the & & 61.9 & 0 & 90.5 & 95.2 \\
\hline & Matsud & & 53.4 & 1.4 & 94.3 & 52.3 & 20.5 & 19.3 & 34.1 & 78.4 & 31.8 & 29.5 & 67.0 & 35.2 \\
\hline & (14) & High-rise & 11.1 & 0 & 81.5 & 74.1 & 3.7 & 14.8 & 44.4 & 85.2 & 37.0 & 40.7 & 96.3 & 85.2 \\
\hline & ounod & Detached & 39.2 & 4.8 & 84.8 & 56.8 & 34.4 & 19.2 & 32.8 & 84.0 & 47.2 & 26.4 & 89.6 & 82.4 \\
\hline & & & 18.5 & 7.4 & 100 & 81.5 & 14.8 & 14.8 & 66.7 & 85.2 & 48.1 & 29.6 & 96.3 & 100 \\
\hline & & & 46.7 & 7.6 & 95.3 & 65.1 & 17.1 & 27.6 & 33.3 & 94.3 & 43.8 & 16.2 & 81.0 & 81.0 \\
\hline & (16) Bara- & Higl & 14.3 & 0 & 71.4 & 85.7 & 0 & 14.3 & 57.1 & 71.4 & 42.9 & 28.6 & 85.7 & 57.1 \\
\hline & & Detached & 46.2 & 8.6 & 86.0 & 51.6 & 9.7 & 32.3 & 31.2 & 80.6 & 28.0 & 34.4 & 65.6 & 55.9 \\
\hline & $\mathrm{A}$ & High-rise & 15.7 & 3.1 & 88.2 & 81.8 & 8.2 & 12.2 & 59.9 & 77.1 & 47.5 & 29.5 & 92.2 & 84.4 \\
\hline & - & Detached & 46.4 & 8.1 & 89.6 & 56.6 & 20.4 & 24.6 & 32.9 & 84.3 & 37.7 & 26.6 & 75.8 & 63.6 \\
\hline & sea & Tot & 31.1 & 5.6 & 88.9 & 69.2 & 14.3 & 18.4 & 46.4 & 80.7 & 42.6 & 28.1 & 84.0 & 74.0 \\
\hline & & Detached & 17.1 & 5.5 & 86.6 & 73.7 & 4.1 & 8.2 & 53.6 & 78.9 & 43.4 & 26.7 & 90.2 & 80.6 \\
\hline & Average & High-rise & 40.6 & 7.9 & 91.0 & 61.3 & 20.7 & 23.4 & 40.1 & 85.5 & 42.1 & 21.6 & 83.6 & 69.7 \\
\hline & & Total & 28.8 & 5.7 & 88.8 & 67.5 & 12.4 & 15.8 & 46.8 & 82.2 & 42.7 & 24.2 & 86.9 & 75.2 \\
\hline
\end{tabular}

(Unit:\%) 
inhabitants, the right side of the Edogawa canal basin toward sea is greatest, followed by the left side, then the right side of the Arakawa canal, followed by the left side toward sea, which is the opposite of that observed for Q.5.

Questions on damage caused by flooding in the past [Q.9, 10,11] Regarding Q.9, for example, 39.9\% of the respondents living in detached houses in the Arakawa canal basin have experienced flooding. On the other hand, only $11.9 \%$ of respondents living in high-rise apartment buildings have experienced flooding.

Also, respondents living in high-rise apartment buildings in the Edo canal basin, few respondents have experienced flooding. For Q.10, half of the respondents living near the downstream reaches of both canal basins fear flooding caused by high tides and tsunamis. Regarding Q.11, compared to the residents of the Edo canal basin, residents of the Arakawa canal basin are 1.4 times as anxious about the strength of the levee against an earthquake.

Questions related to evacuation [Q.12, 13, 14] Approximately 80\% of the respondents in both canal basins are aware of the location of the designated refuge sites. However, even if respondents are aware of the locations of the refuge site, half of the respondents do not consider the refuge site to be safe. In addition, even if the respondents are aware of the location of the refuge site, about $30 \%$ of respondents are unaware of how far the refuge site is from their houses.

Questions related to living environment [Q.15, 16] Regarding Q. 15 and 16, most of the respondents have favorable impressions of their surrounding living environments.

\section{Comparison of responses from respondents from high-rise apartment buildings and detached houses}

Comparisons between detached houses and high-rise apartments by respondents show the following. Regarding Q.5, in the Edo canal basin, the number of respondents who fear flooding is approximately 2.4 times higher among the inhabitants of detached houses compared to residents of high-rise apartments. Similarly, for Q.10, detached house residents are about 2.8 times as likely to fear the risk of flooding compared to the residents of high-rise apartments in both basins. Of the responses obtained for Q.9 in the Arakawa canal basin, 39.9\% of respondents who reside in detached houses have experienced flooding, compared to only $11.9 \%$ of respondents living in high-rise apartment buildings. Similarly, in the Edo canal basin, $20.7 \%$ of respondents residing in detached houses have experienced flooding, while only $4.1 \%$ of respondents in high-rise apartment buildings have had a similar experience.

Figure 6 shows the difference in the attitude toward flooding among tenants from different floors of high-rise apartment buildings (from the first (ground) floor to the 9th floor or more). As shown in Figure 6, there is a change in the perception of the risk associated with flooding (Q. 5, 6 and 10) among tenants in high-rise buildings as one moves upward. Interestingly, respondents who have 


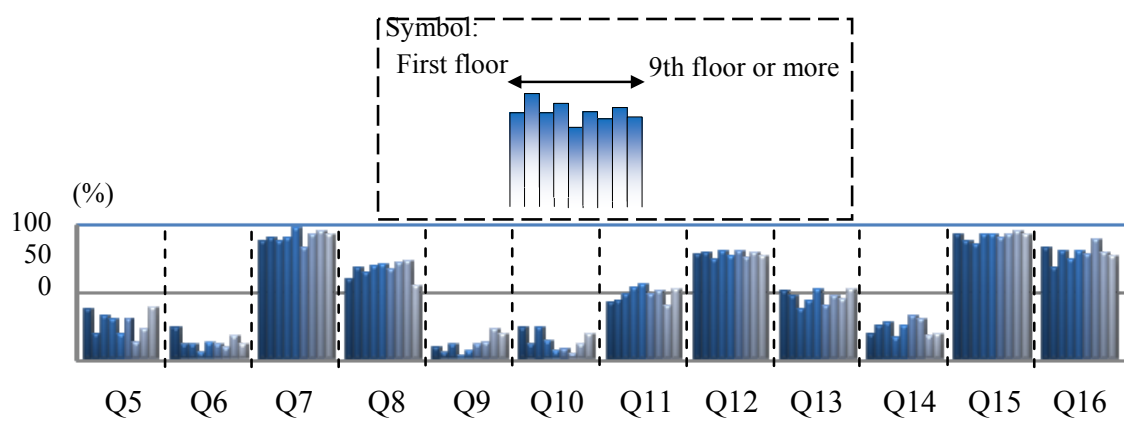

Figure 6: Difference in stories on attitude of residents.

experienced flooding tend to live higher up (Q. 9). For Q. 5 and 10, although numerous respondents residing in the lower stories also fear flooding, respondents who fear flooding the most reside in the mid-level stories. These respondents may not only fear damage associated with flooding, but also damage due to earthquakes or the inconvenience associated with life after flooding.

\section{New flood refuge measures}

Japan has experienced numerous floods due to typhoons and tsunamis. In Tokyo, the Ministry of Land, Infrastructure and Transport, as well as the Tokyo Metropolitan Government are responsible for developing and maintaining the systems for protecting residents from these threats. In the Tokyo Bay area, especially in the "zero meter" area, measures such as dykes and levees have been implemented to prevent flooding. However, one of the measures for reducing the extent of damage during flooding events involves the evacuation of the residents living in the affected area. It is therefore important for the authorities responsible for disaster prevention to improve the attitude of residents toward flood hazards.

At present, several measures are commonly implemented in the normal condition. These include the production and distribution of flood hazard maps to residents. To improve the education of residents regarding flooding disasters, some authorities have also produced animated hazard maps. In addition, emergency training exercises referred to as "DIG" (Disaster, Imagination, $\underline{\text { Game) }}$ or the card game, "Cross road", have been adopted by some local governments $[6,7]$. Specialists in disaster prevention are also sent to elementary schools and other centers to give lectures on flooding. Furthermore, to ensure that residents do not panic in the event of a flood, the responsible authority for disaster prevention give the qualification "readers for disaster prevention" in every towns [8]. In addition, the mechanisms and systems required for disseminating materials and equipment to areas affected by disasters have been developed.

Unfortunately, emergency measures considering the differences in the types of buildings do not exist at present. However, it is hoped that cooperation between the residents of detached houses and high-rise buildings will be initiated and that precautions against flooding will be developed. For example, residents 
of detached houses may be able to use high-rise buildings as refuge sites. In addition, it is hoped that, under the leadership of government, initiatives to increase the height of the floors of detached houses will be implemented.

\section{Conclusions}

The Japanese Cabinet collected information on extant flood mitigation measures by sending questionnaires to 334 municipalities on the outskirts of Tokyo in 2008 [9]. The responses revealed that approximately 53\% of municipalities plan to use buildings above the high-water mark in the event that refuges are flooded. Also, several municipalities plan to use the upper stories of company buildings $(23 \%)$ and apartment buildings $(3 \%)$ and have concluded agreements with the owners of such buildings regarding the handling of flood victims.

We compared the results of the Cabinet investigation against the data we obtained from the residents of detached houses and high-rise buildings in the Arakawa and Edo canal basins of this study.

The attitudes of residents towards flooding were found to vary by area as opposed to house type, and opinions from residents of the two areas were observed to exist. Such differences appear to have arisen in response to differences in the extent of familiarity among residents with the levees of these systems. However, a general difference was observed between the residents of different house types, with the residents of detached houses fearing floods more than the residents of high-rise buildings.

The attitude of residents within high-rise buildings was observed to vary slightly in response to story above ground. Interestingly, although the inhabitants of ground floors were anxious about flooding, the residents living in higher stories were more likely to fear damage associated with earthquakes or be sensitive to the inconvenience associated with daily living after flooding. Furthermore, residents who have experienced flooding previously were most likely to reside in high-rise buildings.

In order to reduce the damage due to flooding, flood mitigation measures and facilities need to be improved. It is also considered necessary to encourage residents to be prepared for flood hazards based on the area in which they live and their house type.

\section{References}

[1] Koutou Flood Control Office, Bureau of Construction, Tokyo Metropolitan Government, Outline of undertakings, http://www.kensetsu.metro.tokyo.jp/.

[2] Bureau of Environment, Tokyo Metropolitan Government, Environment of Tokyo. http://www.kankyo.metro.tokyo.jp/

[3] H. Gotoh, H. Oshiki, Y. Maeno, and T. Takezawa, Attitude of Residents in Tokyo Bay Area toward Flood Hazards, River Basin Management IV, pp.117-126, WIT Press, 2007.

[4] Arakawa-Joryu River Management Office, Outline of Arakawa River, http://www.ktr.mlit.go.jp/arajo/ 
[5] Bureau of General Affairs, Tokyo Metropolitan Government, Map on disaster prevention, http://www2.wagamachi-guide.com/tokyo_bousai/.

[6] e-dig society, "DIG Website", http://www.e-dig.net/0101.html.

[7] Cabinet Office, Government of Japan, Information bulletin on disaster prevention, http://www.bousai.go.jp/.

[8] Bousaishi Training Center, "What is bousashi", http://www.bousaishi.net/.

[9] Cabinet Office, Government of Japan, Report of questionnaire to municipalities on large-scale flooding disaster, http://www.bousai.go.jp/. 